Article

\title{
Utilization of Waste Leather Powders for Highly Effective Removal of Dyes from Water
}

\author{
Liangjun Xia ${ }^{1,2,+} \oplus$, Chen $\mathrm{Li}^{1}{ }^{1+}{ }^{+}$, Sijie Zhou ${ }^{1}$, Zhuan Fu ${ }^{1}$, Yun Wang ${ }^{1}$, Pei Lyu ${ }^{2}$, Jiajing Zhang ${ }^{1}$, \\ Xin Liu ${ }^{1,3}$, Chunhua Zhang ${ }^{1,3, *}$ and Weilin $\mathrm{Xu}^{1, *}$ \\ 1 State Key Laboratory of New Textile Materials and Advanced Processing Technologies, Wuhan Textile \\ University, Wuhan 430200, China; liangjun_xia@hotmail.com (L.X.); 15927512243@163.com (C.L.); \\ sijie_zhou9602@163.com (S.Z.); zhuan_fu1996@163.com (Z.F.); 15527072729@163.com (Y.W.); \\ zjj18672519077@163.com (J.Z.); xinliu_wtu@163.com (X.L.) \\ 2 Institute for Frontier Materials, Deakin University, Geelong, Victoria 3216, Australia; lyup@deakin.edu.au \\ 3 College of Material Science and Engineering, Wuhan Textile University, Wuhan 430073, China \\ * Correspondence: chua_zhang@163.com (C.Z.); weilin_xu0@163.com (W.X.); \\ Tel.:/Fax: +86-027-59367690 (C.Z. \& W.X.) \\ + These authors contributed equally to this work.
}

Received: 24 September 2019; Accepted: 27 October 2019; Published: 1 November 2019

\begin{abstract}
As a natural polymer, leather and its associated industries are known to be the leading economic sector in many countries. However, the huge amounts of leather waste generated from the leather industry causes severe environmental pollution. Herein, cow leather (CL) powders were prepared using a homemade machine and used as a low-cost adsorbent for the effective removal of reactive dyes from wastewater. The as-prepared CL powders exhibited dot-like, rod-like, and fiber-like morphologies. A Fourier transform infrared analysis and an $\mathrm{x}$-ray diffraction analysis demonstrated that the CL powders retained the main structure of the protein contained in it. In addition, an improvement in thermal stability was also observed for the CL powders. Dye adsorption experiments indicate that the CL powders showed the highly effective removal of C.I. Reactive Red 120 (RR120), C.I. Reactive Yellow 127 (RY127), and C.I. Reactive Blue 222 (RB222) with the adsorption capacity of $167.0,178.9$, and $129.6 \mathrm{mg} \cdot \mathrm{g}^{-1}$, respectively. The Langmuir, pseudo-second order, and intraparticle diffusion models could well depict the adsorption equilibrium and kinetics of CL powders toward the investigated reactive dyes. The as-prepared CL powders can be used as a potential adsorbent in the treatment of dye contaminated wastewater. Future studies will mainly focus on the application of the adsorbed CL powders for the pigment printing of textile materials.
\end{abstract}

Keywords: natural polymer; leather waste; powder; dyes; adsorption; wastewater

\section{Introduction}

Water security is certain to be a major topic facing humanity. It has been reported that the freshwater ecosystem only occupies nearly $1 \%$ of the Earth's surface [1]. Hence, as the global population increases, enormous stress on the requirement of freshwater for both people and nature will be generated yearly [2]. Additionally, rising industrialization, especially that of the textile industry, consumes large amounts of water and discharges wastewater with deep colors [3,4]. Although we developed an environmentally friendly dyeing method to conserve water consumption and mitigate water pollution in our previous study [5], the elimination of dyes in conventional textile effluents is still of great importance to the whole textile industry.

Recently, various technologies such as adsorption [6-9], photochemical degradation [10,11], membrane filtration $[12,13]$, and biological treatment $[14,15]$ have become available for color removal 
from dye contaminated water. Based on sustainable development, adsorption using waste materials has been considered to be the most promising technology among these approaches [16].

Leather products in the form of protein are widely used in daily human life [17]. However, it is reported that nearly $30 \%$ of the leftover leather materials processed in tanneries is abandoned [18]. In addition, statistical data on the leather industry shows that nearly 0.15 million tons of leather solid-waste is produced annually in India, and 1.4 million tons in China [17]. The arbitrary disposal of leather shavings and products inevitably results in great damage to the environment, but also represents a considerable waste of existing resources. Therefore, the reuse of leather waste, and in particular secondary waste, has become an important research problem.

Significant research and attention in a number of publications has focused on the isolation and production of collagens from leather waste, and on more detailed reviews of the pretreatment method such as chemical treatment (oxidation of hydrolyzes) and enzymatic digestion [17,19]. An increasing number of studies consider the incorporation of leather as a filler in polymers including rubbers (natural or synthetic) [20-22], poly (vinyl butyral) [23], and polyamide [24]. Moreover, a series of methods for processing leather waste including waste dumps [17], combustion [25], pyrolysis [26], carbonization [27] fertilizer [28], and pigments [29] have been extensively employed to treat leather waste. However, most of these methods are likely to generate secondary pollutants, and can only be applied in limited application areas, which may put considerable pressure on highly fragile ecological environments.

Powder, a popular and low-cost technology, has been proven to be an effective and economical absorbent for removing dyes from wastewater [8,16,30]. In our previous studies, silk fibroin powder [16], down powder [31,32], and needle down powder [33] were examined in terms of their capacity to remove dyes from dyeing effluents. However, to the best of our knowledge, there have only been a few reported studies on the preparation of leather powder and its applications in dye removal, which is mainly due to its unique structure containing strong hydrogen and ionic bonding, thus making it difficult to grind into fine or superfine powder without high-pressure homogenization or chemical pretreatment.

In this paper, a homemade instrument [34,35], which can be used to grind both primary and secondary leather waste into powders at room temperature and atmospheric pressure without chemical pretreatment, was employed to produce the leather powder. In addition, the morphologies, microstructures, and thermo-gravimetric analysis were considered to understand the nature of this leather. Finally, three kinds of reactive dyes including C.I. Reactive Red 120 (RR120), C.I. Reactive Yellow 167 (RY167), and C.I. Reactive Blue 222 (RB222) were used to examine the removal capacity of leather powder. The effects of $\mathrm{pH}$ value, contact time, and the adsorption isotherm and kinetic models were systematically studied. This is the first-time that leather powder has been investigated in the application of dye removal from wastewater.

\section{Materials and Methods}

\subsection{Materials}

Waste cow leather (CL) was supplied by a local tannery in Zhejiang Province, China. Acetic acid (HAC), sodium hydrogen phosphate $\left(\mathrm{Na}_{2} \mathrm{HPO}_{4} \cdot 12 \mathrm{H}_{2} \mathrm{O}\right)$, citric acid monohydrate $\left(\mathrm{C}_{4} \mathrm{H}_{2} \mathrm{O}_{7} \cdot \mathrm{H}_{2} \mathrm{O}\right)$, Sodium hypochlorite $(\mathrm{NaClO})$, and absolute ethanol were purchased from Sinopharm Chemical Reagent Co. Ltd., Shanghai, China. The RR120, RY167, and RB222 dyes were kindly supplied by Luthai Textile Co. Ltd., Shandong, China, and the chemical structures of the dyes are shown in Figure 1. Deionized water was employed throughout the experiments. All chemicals were of analytical grade and used as received. 
(a)

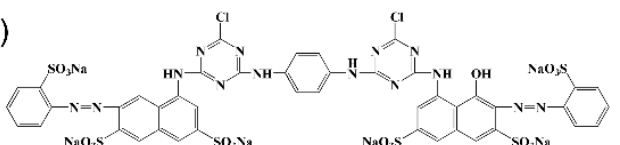

(b)

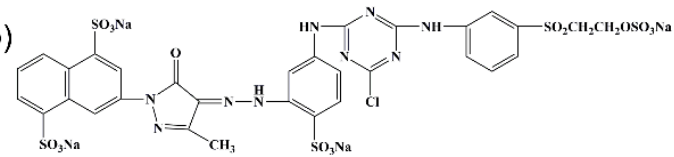

(c)

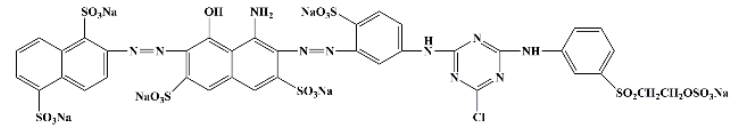

Figure 1. Chemical structures of (a) RR120, (b) RY167, and (c) RB222, respectively.

\subsection{Preparation of CL Powder}

The preparation procedures of the CL powders are illustrated in Figure 2. Typical procedures were performed by categorizing the waste leathers into different colors. In this experiment, the waste leathers with white or light blue colors were selected for the removal of dyes from water. Then, the categorized waste leathers were disinfected using a $0.5 \% \mathrm{NaClO}$ solution at room temperature. After the residual moisture of the waste leather was removed, the leather was cut into short pieces (ca. $10 \mathrm{~mm}$ ) using a rotary blade, and then ground between two milling pans using a special method that employed a homemade instrument, which was previously reported in our studies for the preparation of superfine wool and down powder [34,36]. The mills had special properties such as very low heat generation and high anti-abrasion properties. The leather pieces could be crushed into fine leather powder under the mechanical action, which included pressure, drawing, torsion, and sheer action.

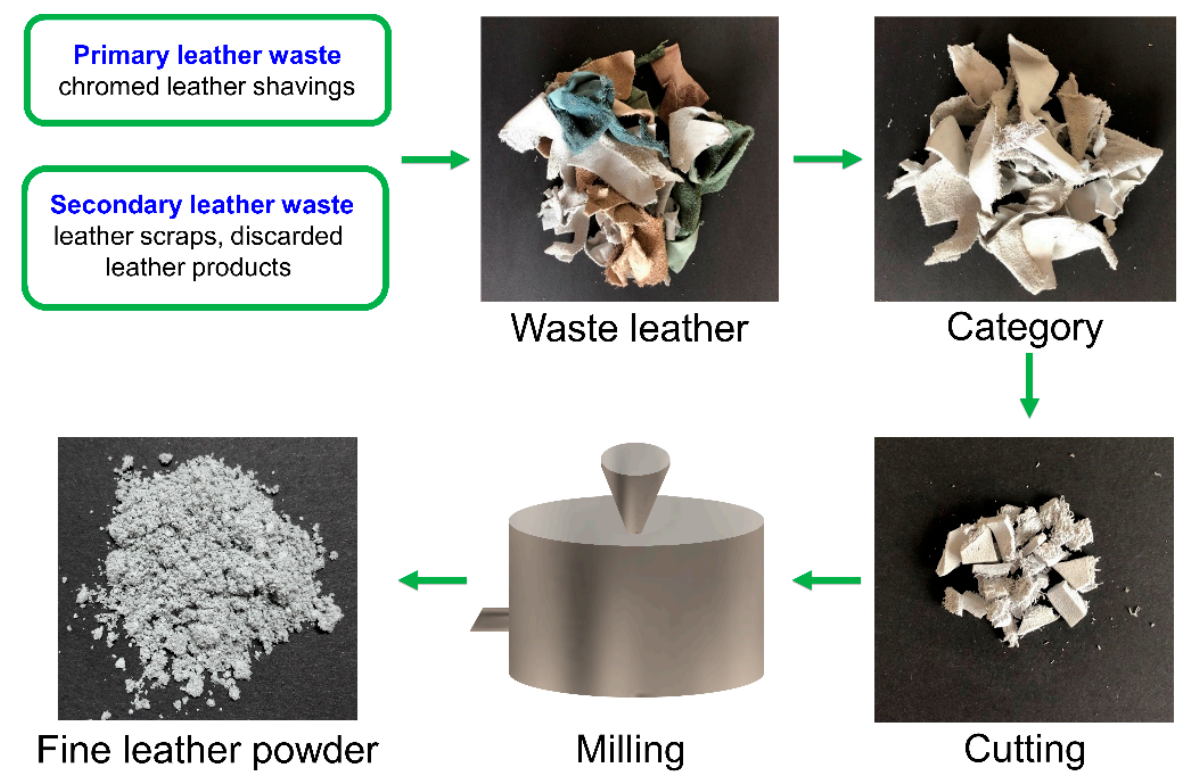

Figure 2. Preparation procedure for the CL powder.

\subsection{Adsorption Study}

Typically, reactive dyes play an essential role in the textile dyeing industry [37], which occupy more than $30 \%$ of the total dye market share, and this number is increasing dramatically [38]. Therefore, in the present study, three kinds of dyes (RR120, RY167, and RB222) that are usually employed in the cotton dyeing industry were selected as representative dyes to prepare the dye-contaminated wastewater. The $\mathrm{pH}$ of the dye solutions was adjusted using $\mathrm{HAC}, \mathrm{Na}_{2} \mathrm{HPO}_{4} \cdot 12 \mathrm{H}_{2} \mathrm{O}$, and $\mathrm{C}_{4} \mathrm{H}_{2} \mathrm{O}_{7} \cdot \mathrm{H}_{2} \mathrm{O}_{\text {. }}$ A series of batch experiments were conducted by placing $0.3 \mathrm{~g}$ of $\mathrm{CL}$ powders evenly inside the conical flasks filled with $50 \mathrm{~mL}$ of different dye solutions at room temperature $\left(30^{\circ} \mathrm{C}\right)$. The parameters of $\mathrm{pH}$ (3-8), contact time (0-100 $\mathrm{min})$, and dye concentration (50-1200 $\mathrm{mg} \cdot \mathrm{L}^{-1}$ ) were investigated to examine the adsorption properties of CL powder toward the three dyes. 
The dye removal efficiency (\% RE) and the adsorption capacity at equilibrium $\left(Q_{e}, \mathrm{mg}^{-1} \mathrm{~g}^{-1}\right.$ was calculated using Equations (1) and (2) [39,40], respectively.

$$
\begin{gathered}
R E=\frac{\left(C_{0}-C_{e}\right)}{C_{0}} \times 100 \% \\
Q_{\mathrm{e}}=\frac{\left(C_{0}-C_{e}\right) V}{m}
\end{gathered}
$$

where $C_{0}$ and $C_{e}$ are the initial and equilibrium concentrations of the dye solutions $\left(\mathrm{mg} \cdot \mathrm{L}^{-1}\right)$, respectively; $V$ is the volume of dye solution (L); and $m$ is the mass of the CL powder.

\subsection{Characterization}

Photographs of the CL and CL powder were measured using a digital camera (Canon EOS 80D). The maximum Feret diameter (MFD) of CL powder was observed using optical microscopy (CKX41, Olympus Co., Tokyo, Japan). The CL powder was ultrasonically dispersed in an ethanol-water mixture (90:10 wt.\%). Then, the CL powder solution was placed onto a glass slide for observation. The typical morphology of the CL powders was revealed using Image Pro Plus (edition 6.0). Morphologies of the CL and CL powder were examined using scanning electron microscopy (SEM) (JSM-6510LV, JEOL Ltd., Tokyo, Japan). Samples were sputter-coated with a thin gold layer before testing. Dynamic light scattering (DLS) measurements were used to examine the mean zeta potential (ZP) analyses of the dyes and CL powders using a Zetasizer ZEN3600 instrument (Malvern Instruments Ltd., Malvern, UK) at room temperature. Fourier transform infrared spectroscopy (FTIR) of the CL and CL powder were characterized on a Bruker LUMOS FTIR microscope (Bruker corporation, Karlsruhe, Germany). FTIR was employed to record the spectra of the films from 4000 to $1000 \mathrm{~cm}^{-1}$ with 256 scans at the resolution of $4 \mathrm{~cm}^{-1}$. All measurements were repeated three times from three different spots on the same sample. X-ray diffraction (XRD) was performed on an X'pert Pro, PANalytical B.V., Holland using $\mathrm{Cu} \mathrm{k} \alpha$ radiation where the irradiation conditions were $40 \mathrm{kV}$ and $40 \mathrm{~mA}$. Samples were scanned from 5 to $70^{\circ}(2 \theta)$ with a step length of $0.02^{\circ}$. Thermo-gravimetric analysis (TGA) and derivative thermogravimetric (DTG) curves were obtianed by using NETZSCH TG 209 F1 (Netzsch Ltd., Hanau, Germany) in flowing nitrogen gas $\left(20 \mathrm{~mL} \cdot \mathrm{min}^{-1}\right)$. The samples were heated from $25^{\circ} \mathrm{C}$ up to $800{ }^{\circ} \mathrm{C}$ with a heating rate of $10^{\circ} \mathrm{C} \cdot \mathrm{min}^{-1}$.

\section{Results and Discussion}

\subsection{Characterization of $C L$ and $C L$ Powder}

The morphologies of CL and the CL powder were examined using SEM. As shown in Figure 3, the photographs and micrographs exhibited significant changes in the morphologies of the CL and CL powder. The images in Figure 3a revealed that the smooth surface of the CL was compact, indicating that it is difficult to triturate $C L$ into powder. In addition, various irregular shaped fibrils were present on the opposite side of the smooth surface of the CL (Figure 3b). Figure 3c shows that the CL was crushed into very small particles, especially in diameter, and most of these exhibited fiber-like and rod-like morphologies with a diameter of 5-10 $\mu \mathrm{m}$ (obtained from ImageJ Pro Plus).

The measurement of particle sizes varies in complexity depending on the shape of the particle. Generally, the particle size of a spherical object can be unambiguously and quantitatively defined by its diameter, due to the same size in different orientations (0-180 degree). For irregular particles, Feret's diameter is a frequently used descriptor for the evaluation of particle size distribution, according to previous literature [41-45]. The maximum Feret's diameter (MFD) is defined is the longest distance between two points on the perimeter between which a line can be drawn within the perimeter. 


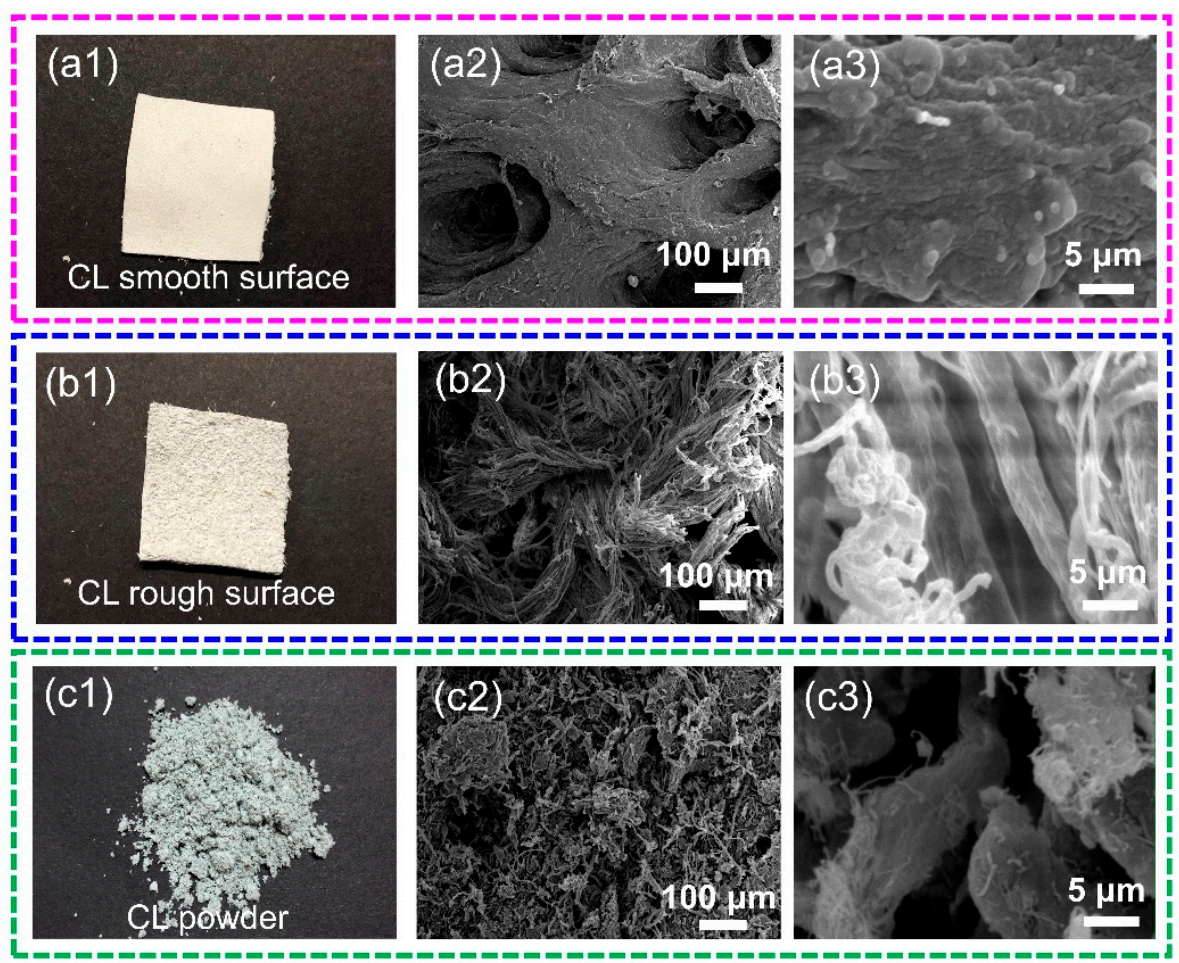

Figure 3. (a1-a3) Photographs and SEM images for the smooth surface of CL; (b1-b3) photographs and SEM images for the rough surface of CL; (c1-c3) photographs and SEM images of CL powders.

Optical microscope images of CL powders revealed a different morphology, shape, and size of the particles, which can be classified into three types: dot-like particles, rod-like particles, and fiber-like particles, respectively (as shown in Figure 4a-c). This could be ascribed to the structural inconsistency of CL (CL smooth surface and CL rough surface), which might enable uniform force during milling by using a homemade instrument. To accurately describe the morphological features of the CL powders, numerous particles for each shape were analyzed from the optical microscope images and the value of the averaged MDF were calculated. As depicted in Figure 4, dot-like particles had an average MFD of $1.6 \mu \mathrm{m}$, rod-like particles had an average MFD of $17.8 \mu \mathrm{m}$, and fiber-like particle had an average MFD of $40.1 \mu \mathrm{m}$, respectively. The morphologies of the CL powder were consistent with the SEM images.

Figure 5a shows the FTIR spectra of the CL and CL powder. The CL exhibited characteristic peaks at $3306 \mathrm{~cm}^{-1}$ (the combined effect of N-H and O-H stretching vibrations), $2920 \mathrm{~cm}^{-1}$ (C-H asymmetric stretching vibrations), $2850 \mathrm{~cm}^{-1}$ (C-H symmetric stretching vibrations), $1633 \mathrm{~cm}^{-1}$ (amide I), and $1554 \mathrm{~cm}^{-1}$ (amide II). These bands are similar to the FTIR spectra of protein fibers such as silk, wool, and down fibers due to the similarities in the chemical structures of keratins [34,35]. In comparison, the CL powder exhibited characteristic peaks at $3309 \mathrm{~cm}^{-1}, 2926 \mathrm{~cm}^{-1}, 2861 \mathrm{~cm}^{-1}, 1686 \mathrm{~cm} \mathrm{~cm}^{-1}$, and $1552 \mathrm{~cm} \mathrm{~cm}^{-1}$, indicating the main structure of keratins in the CL powder. Furthermore, no new bands could be seen in the spectra of the CL powder, suggesting that the milling process does not produce new bands. The sharper peak at $3309 \mathrm{~cm}^{-1}$ shifted to $3334 \mathrm{~cm}^{-1}$ (broad peak) in Figure $5 \mathrm{a}$. This shift change confirms the transformation of strong hydrogen bonds to weak hydrogen bonds due to the milling process $[35,46]$. Meanwhile, the band of amide I $\left(1633 \mathrm{~cm}^{-1}\right)$ shifted to a higher wavenumber $\left(1686 \mathrm{~cm}^{-1}\right)$ after milling. These two peaks can be ascribed to the $\beta$-sheet [47]. The FTIR spectra of CL exhibited more significant $\beta$-sheet conformation peaks in amide I and amide II than the CL powder, which indicates some changes in the $\mathrm{C}=\mathrm{O}$ groups. 

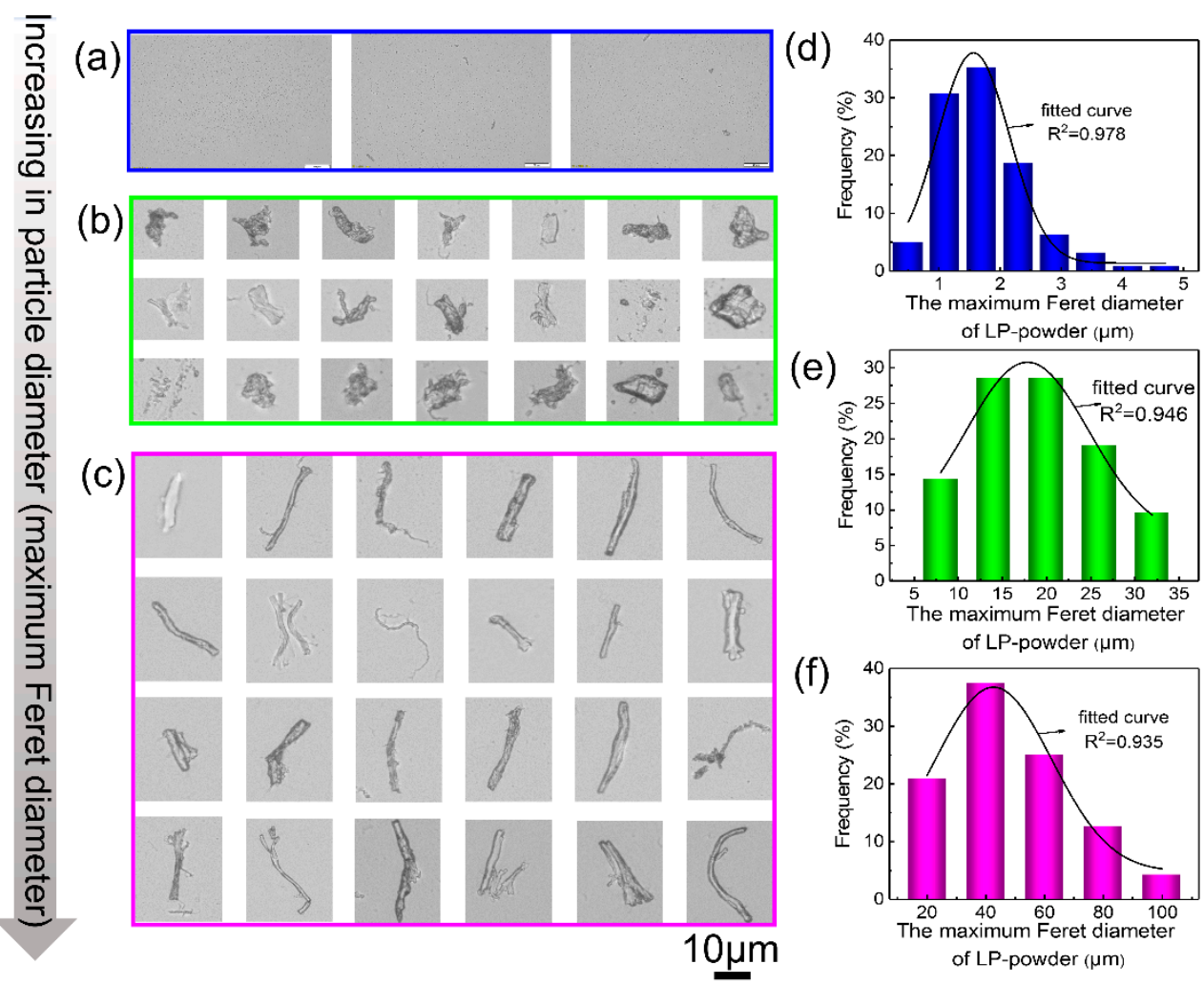

Figure 4. (a-c) Morphologies of the dot-like (a), rod-like (b), and fiber-like (c) particles; $(\mathbf{d}-\mathbf{f})$ histograms of the maximum Feret diameter of the dot-like (d), rod-like (e), and fiber-like (f) particles.
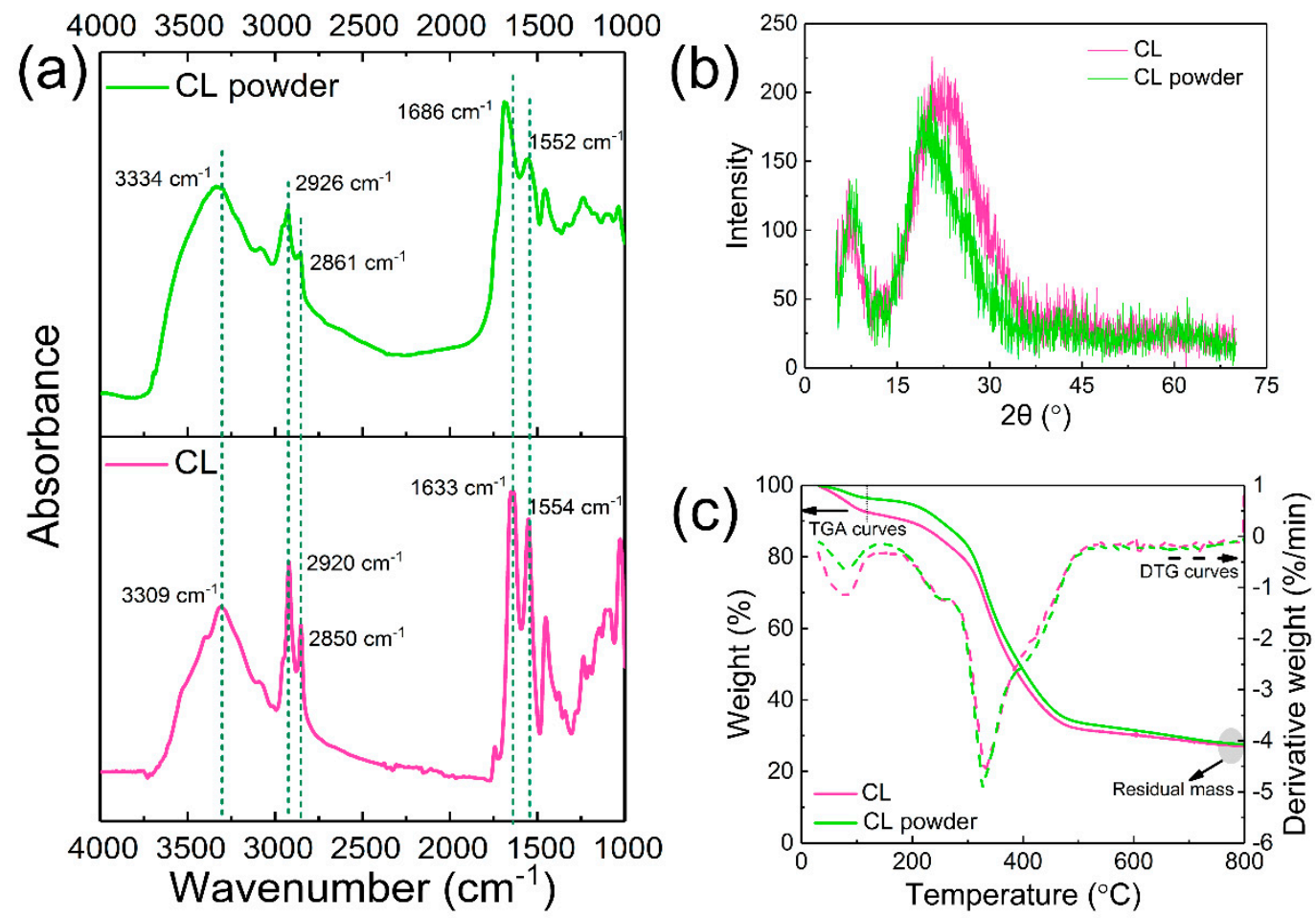

Figure 5. (a) FTIR spectra of CL and CL powder; (b) XRD curves of CL and CL powder; (c) TGA (left) and DTG (right) curves of CL and CL powder.

To investigate the effect of the developed method on the intensity of CL, x-ray diffraction was performed. As shown in Figure $5 b$, all x-ray diffractograms exhibited a minor peak at $7.9^{\circ}(2 \theta$ angle), 
a broad peak at $22^{\circ}\left(2 \theta\right.$ angle), and a minor peak at $29.7^{\circ}$. The first intense peak at $7.9^{\circ}$ for the $\mathrm{CL}$ and CL powder was consistent with the leather shavings in the studies of Li et al. [48]. As depicted in Figure $5 b$, the intensity of the peak at $7.9^{\circ}$ for the CL remained the same after grinding. Furthermore, the peak intensities of the CL powder (a broad peak around $22^{\circ}$ ) were lower than for the $C L$, indicating a slight decrease in the crystallinity of the CL. This minor reduction could be ascribed to the crystal being destroyed in the milling process. Moreover, both the CL and CL powder maintained the triple helical structure located at around $27.90^{\circ}$. Thus, the CL powder could maintain its original structure after milling.

The TGA and DTG curves for the CL and CL powder are presented in Figure 5c. The TGA curve for the $C L$ powder was similar to that of the $C L$, which exhibited a two-stage degradation. The first stage of degradation (stage-I), between 35 and $120^{\circ} \mathrm{C}$, can be attributed to water evaporation and small molecular substances. The second stage of degradation (stage-II), between 120 and $800^{\circ} \mathrm{C}$, is associated with the decomposition of peptide bonds [34,49]. As depicted in Figure $5 c$, the weight loss of the absorbed water, bound water, and small molecular substances in CL was about $8.5 \%$ (stage-I). For the CL powder, the water content was reduced to $4.1 \%$ when compared with the CL. This decrease can be ascribed to the volatilization of small molecular substances and the destruction of the polar groups during milling. Meanwhile, the decomposition temperature plotted in the DTG curves was about $330^{\circ} \mathrm{C}$ for both the $\mathrm{CL}$ and $\mathrm{CL}$ powder, and the residual of the $\mathrm{CL}$ powder $(27.6 \%)$ increased when compared with the CL (27.0\%). According to our previous research, another natural protein powder (superfine down powder) fabricated using this method exhibited the same trend for the enhancement of the residual (TGA in a $\mathrm{N}_{2}$ atmosphere) $[50,51]$. Therefore, the enhancement in thermal stability could be attributed to the higher relative presence of retained carbon elements in the CL powder when compared to the noncarbon elements such as $\mathrm{NH}_{3}$ lost during the milling process.

\subsection{Adsorption Isotherms}

Solution $\mathrm{pH}$ significantly affects the adsorption performance of an adsorbent, especially the surface charge of the adsorbent and the dissociation degree of the dye molecule [8]. The curves in Figure 6a show the influence of solution $\mathrm{pH}$ on the adsorption of RR120, RY167, and RB222 onto CL powder within the $\mathrm{pH}$ range of 3.0-8.0 at an initial concentration of $50 \mathrm{mg} \cdot \mathrm{L}^{-1}$. The maximum adsorption efficiency occurred at a $\mathrm{pH}$ of 3.0 for all of the investigated dyes, which were $94.0 \%, 92.5 \%$, and $99.9 \%$ for RR120, RY167, and RB222 at an initial dye concentration of $50 \mathrm{mg} \cdot \mathrm{L}^{-1}$, respectively. This can be ascribed to the dissociation of these anionic dyes in the aqueous solution [8]. Furthermore, as shown in Figure $6 \mathrm{~b}$ the electrostatic attraction between the positively charged CL powder and the negatively charged dye molecule were significantly enhanced under acidic conditions [39], resulting in the high removal efficiency.

The adsorption isotherm is generally applied to elucidate the relationship between the adsorbent and dyes under equilibrium conditions. Moreover, the maximum adsorption capacities of the adsorbent toward dyes can be calculated according to the adsorption isotherm [52]. In this study, two well-known Langmuir and Freundlich adsorption isotherms were employed to obtain deeper insight into the removal of reactive dyes by the CL powders. The Langmuir isotherm describes the single layer adsorption on a homogeneous surface of the adsorbent [52], which can be expressed as Equation (3) [53,54],

$$
\frac{C_{e}}{Q_{e}}=\frac{1}{K_{l} Q_{m}}+\frac{C_{e}}{Q_{m}}
$$

where $C_{e}$ is the equilibrium concentration of the reactive dyes $\left(\mathrm{mg} \cdot \mathrm{L}^{-1}\right) ; Q_{e}$ is the equilibrium adsorption capacity of the reactive dyes adsorbed onto the CL powders $\left(\mathrm{mg} \cdot \mathrm{L}^{-1}\right) ; Q_{m}\left(\mathrm{mg} \cdot \mathrm{L}^{-1}\right)$ represents the maximum adsorption capacity; and $K_{l}\left(\mathrm{~L} \cdot \mathrm{mg}^{-1}\right)$ is a constant of the Langmuir isotherm.

Furthermore, the basic characteristic of the Langmuir isotherm model can be expressed by the dimensionless differentiation factor $\left(R_{1}\right)$, which is defined as Equation (4) [53], 


$$
R_{l}=\frac{1}{1+K_{l} C_{0}}
$$

Herein, the adsorption is typically considered irreversible $\left(R_{1}=0\right)$, favorable $\left(0<R_{1}<1\right)$, linear $\left(R_{1}=1\right)$, or unfavorable $\left(R_{1}>1\right)$, respectively.

Additionally, the Freundlich isotherm explains the multilayer adsorption on a heterogeneous surface relating to varied non-ideal conditions [52], which can be expressed as Equation (5) [53,54],

$$
\ln Q_{e}=\ln K_{f}+\frac{1}{n} \ln C_{e}
$$

where $K_{f}$ and $\mathrm{n}$ are empirical constants of the Freundlich adsorption model

Figure 6d,e show the Langmuir and Freundlich adsorption isotherms of the reactive dyes onto the CL powders, respectively. The adsorption capacity generally affects the practical application of an adsorbent [55], which can be estimated according to the Langmuir and Freundlich isotherm models $[53,56]$. Therefore, the values of $Q_{m}$ and $K_{l}$ from the Langmuir isotherm model were calculated according to the slope and intercept for the linear plot of $C_{e} / Q_{e}$ versus $C_{\mathrm{e}}$, and their values are summarized in Table 1. Additionally, the constants of $K_{f}$ and $n$ for the Freundlich isotherm model were also calculated and their values are also listed in Table 1.

(a)
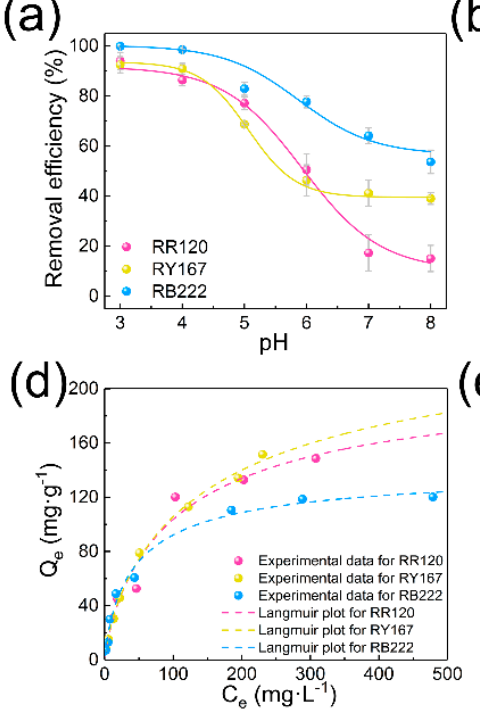

(b)

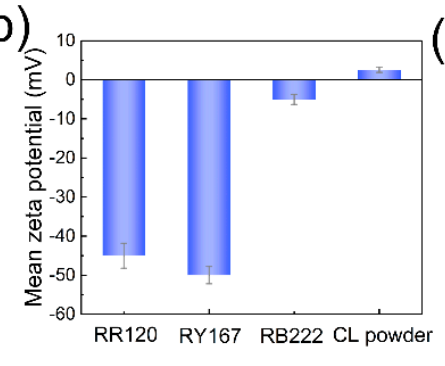

(e)

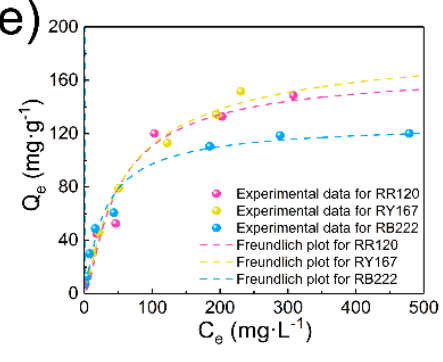

(c)

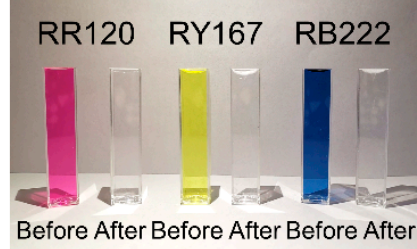

(f)

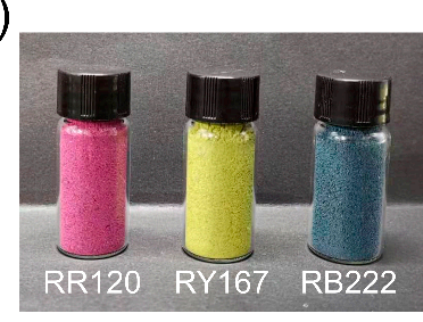

Figure 6. (a) Effect of $\mathrm{pH}$ on the adsorption of RR120, RY167, and RB222 onto the CL powders ( $\mathrm{m}=0.3 \mathrm{~g}$, $\left.\mathrm{V}=50 \mathrm{~mL}, \mathrm{C}_{0}=50 \mathrm{mg} \cdot \mathrm{L}^{-1}, \mathrm{~T}=30^{\circ} \mathrm{C}, \mathrm{T}=100 \mathrm{~min}\right) ;(\mathbf{b})$ mean zeta potential of RR120, RY167, RB222, and CL powders, respectively; (c) photograph of the dye solution before and after the adsorption by the CL powders at the $\mathrm{pH}$ of 3.0 and initial concentration of $50 \mathrm{mg} \cdot \mathrm{L}^{-1}$; (d) Langmuir and (e) Freundlich adsorption isotherms for the adsorption of RR120, RY167, and RB222 by the CL powders ( $\mathrm{m}=0.3 \mathrm{~g}$, $\mathrm{V}=50 \mathrm{~mL}, \mathrm{pH}=3.0, \mathrm{~T}=30^{\circ} \mathrm{C}$ ); (f) photograph of the CL powders after the adsorption of RR120, RY167, and RB22, respectively.

Table 1. Langmuir and Freundlich isotherm parameters for the adsorption of RR120, RY167, and RB222

\begin{tabular}{|c|c|c|c|c|c|c|}
\hline \multirow{2}{*}{ Dyes } & \multicolumn{3}{|c|}{ Langmuir Isotherm } & \multicolumn{3}{|c|}{ Freundlich Isotherm } \\
\hline & $Q_{m}\left(\mathrm{mg} \cdot \mathrm{g}^{-1}\right)$ & $K_{l}\left(\mathrm{~L} \cdot \mathrm{mg}^{-1}\right)$ & $R^{2}$ & $K_{f}\left(\mathrm{mg} \cdot \mathrm{g}^{-1}\right)\left(\mathrm{L} \cdot \mathrm{mg}^{-1}\right)^{1 / n}$ & $1 / n$ & $R^{2}$ \\
\hline RR120 & 167.0 & 0.0229 & 0.9813 & 7.5268 & 0.5548 & 0.9231 \\
\hline RY167 & 178.9 & 0.0174 & 0.9953 & 6.4474 & 0.5946 & 0.9863 \\
\hline RB222 & 129.5 & 0.0300 & 0.9824 & 8.0707 & 0.4877 & 0.9622 \\
\hline
\end{tabular}
onto the CL powders. 
As can be seen from Table 1, the Langmuir correlation coefficients $\left(R^{2}\right)$ for the RR120, RY167, and RB222 were 0.9813, 0.9953, and 09823, respectively, which were higher than the Freundlich correlation coefficients $\left(R^{2}\right)$ for the reactive dyes. Therefore, the adsorption of RR120, RY167, and RB222 onto the CL powders can be well described by the Langmuir isotherm models. Moreover, the $R_{1}$ values calculated for RR120, RY167, and RB222 were found to be $0<R_{1}<1$, suggesting that the adsorption of reactive dyes onto the CL powders occurs spontaneously [52]. In addition, according to the Langmuir equation, the calculated maximum adsorption capacity of RR120, RY167, and RB222 onto the CL powder were $167.0,178.9$, and $129.6 \mathrm{mg} \cdot \mathrm{g}^{-1}$, respectively. Hence, the excellent adsorption capacity of CL powders can mainly be ascribed to the strong electrostatic interactions between the positively charged CL powder and negatively charged dye molecules under acid conditions. As shown in Figure $6 \mathrm{f}$, after the adsorption process, the adsorbed CL powders were collected by the extraction filtration method under negative pressure, followed by drying in an oven at room temperature.

\subsection{Adsorption Kinetics}

Figure 7 shows the adsorption rate of RR120, RY167, and RB222 onto the CL powders. It is clear that all dyes exhibited rapid adsorption onto the CL powders during the first $5 \mathrm{~min}$ in the initial dye concentration range of 50 to $300 \mathrm{mg} \cdot \mathrm{L}^{-1}$, which is mainly due to the strong electrostatic attraction between the adsorbate and adsorbent as well as the high dye concentration difference between the interior and exterior of the adsorbent [16]. Additionally, the active binding sites on the CL powders were quickly occupied by the dyes in a random manner, which contributed to the rapid enhancement in the adsorption process. After that, the adsorption equilibrium was obtained within approximately $10 \mathrm{~min}$, which can be ascribed to the increased surface coverage of the CL powders [55]. At this stage, most of the dyes were absorbed onto the CL powders with the removal efficiency of more than $95 \%$ at the initial dye concentration range of 50 to $300 \mathrm{mg} \cdot \mathrm{L}^{-1}$.
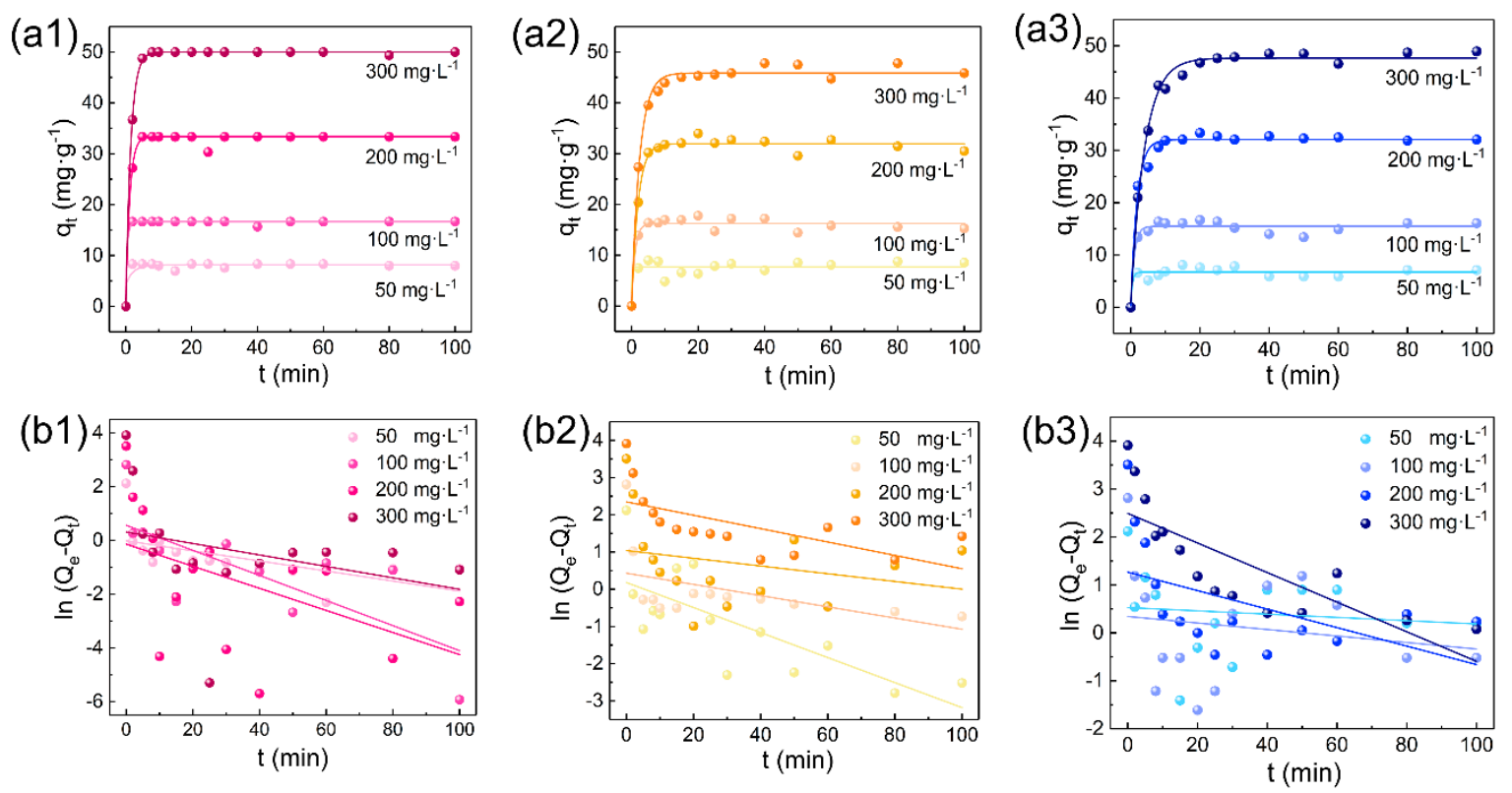

Figure 7. Effect of contact time on the adsorption of (a1) RR120, (a2) RY167, and (a3) RB222, respectively $\left(\mathrm{m}=0.3 \mathrm{~g}, \mathrm{~V}=50 \mathrm{~mL}, \mathrm{C}_{0}=50,100,200\right.$, and $300 \mathrm{mg} \cdot \mathrm{L}^{-1}, \mathrm{~T}=30^{\circ} \mathrm{C}, \mathrm{pH}=3.0$ ); pseudo-first order kinetics for the adsorption of (b1) RR120, (b2) RY167, and (b3) RB222 onto the CL powders, respectively $\left(\mathrm{m}=0.3 \mathrm{~g}, \mathrm{~V}=50 \mathrm{~mL}, \mathrm{C}_{0}=50,100,200\right.$, and $\left.300 \mathrm{mg} \cdot \mathrm{L}^{-1}, \mathrm{~T}=30^{\circ} \mathrm{C}, \mathrm{pH}=3.0\right)$.

To further understand the adsorption mechanism of the CL powders toward the investigated dyes, three kinetic models including the pseudo-first order, pseudo-second order, and intraparticle 
diffusion kinetic models were considered. These kinetic models are expressed as Equations (6)-(8), respectively [57-61].

$$
\begin{gathered}
\ln \left(Q_{e}-Q_{t}\right)=\ln Q_{t}-k_{1} t \\
\frac{t}{Q_{t}}=\frac{1}{k_{2} Q_{e}^{2}}+\frac{\mathrm{t}}{Q_{e}} \\
Q_{t}=k_{p} t^{1 / 2}+C
\end{gathered}
$$

where $k_{1}\left(\mathrm{~g} \cdot \mathrm{mg}^{-1} \cdot \mathrm{min}^{-1}\right)$ and $k_{2}\left(\mathrm{~g} \cdot \mathrm{mg}^{-1} \cdot \mathrm{min}^{-1}\right)$ are the rate constants of the pseudo-first order and second order models; $Q_{e}\left(\mathrm{mg} \cdot \mathrm{g}^{-1}\right)$ and $Q_{t}\left(\mathrm{mg} \cdot \mathrm{g}^{-1}\right)$ are the adsorption capacities at equilibrium and at time $t(\mathrm{~min}) ; \mathrm{h}\left(\mathrm{mg} \cdot \mathrm{g}^{-1} \cdot \mathrm{min}^{-1}\right)$ is the initial adsorption rate of the pseudo-second order kinetics; $k_{p}$ $\left(\mathrm{g} \cdot \mathrm{mg}^{-1} \cdot \mathrm{min}^{-1}\right)$ is the rate constant of the intraparticle diffusion model; and $C$ is a constant characterizing boundary layer thickness.

Figures 7 and $8 \mathrm{a}$ display the plots of $\ln \left(Q_{\mathrm{e}}-Q_{\mathrm{t}}\right)$ versus $\mathrm{t}$ for the pseudo-first order and the plots of $t / q_{t}$ versus $t$ for the pseudo-second order for the absorption of RR120, RY167, and RB222 at the initial dye concentrations ranging from 50 to $300 \mathrm{mg} \cdot \mathrm{L}^{-1}$. It is obvious that the plots were better fitted in Figure 8a1-a3 for the absorption of RR120, RY167, and RB222 by the CL powders than in Figure 7b1-b3. Moreover, from the correlation coefficient $\left(R^{2}\right)$ values summarized in Table 2, the pseudo-second-order model of the investigated dyes with different initial dye concentrations was higher than 0.99 . Furthermore, as listed in Table 2 , the theoretical adsorption capacity $\left(Q_{e, \text { cal }}\right)$ obtained from the pseudo-second order model was closer to the actual adsorption capacity $\left(Q_{e, \exp }\right)$. Therefore, the pseudo-second order model is very suitable for explaining the dye removal from the wastewater by the CL powders. On the other hand, as can be seen from Figure 8b1-b3, the intraparticle diffusion was conducted by a two-step adsorption that requires separate analysis. During the first step, the adsorption of reactive dyes increased sharply, suggesting that the reactive dyes such as RR120, RY167, and RB222 diffused rapidly from the dye liquors to the external surface of the CL powders. After reaching the external surface of the CL powders, these dye molecules were attached to the accessible active sites through electrostatic attractions. After that, during the second step, the surface of the CL powders became saturated with the reactive dyes, leading to their constant diffusion.
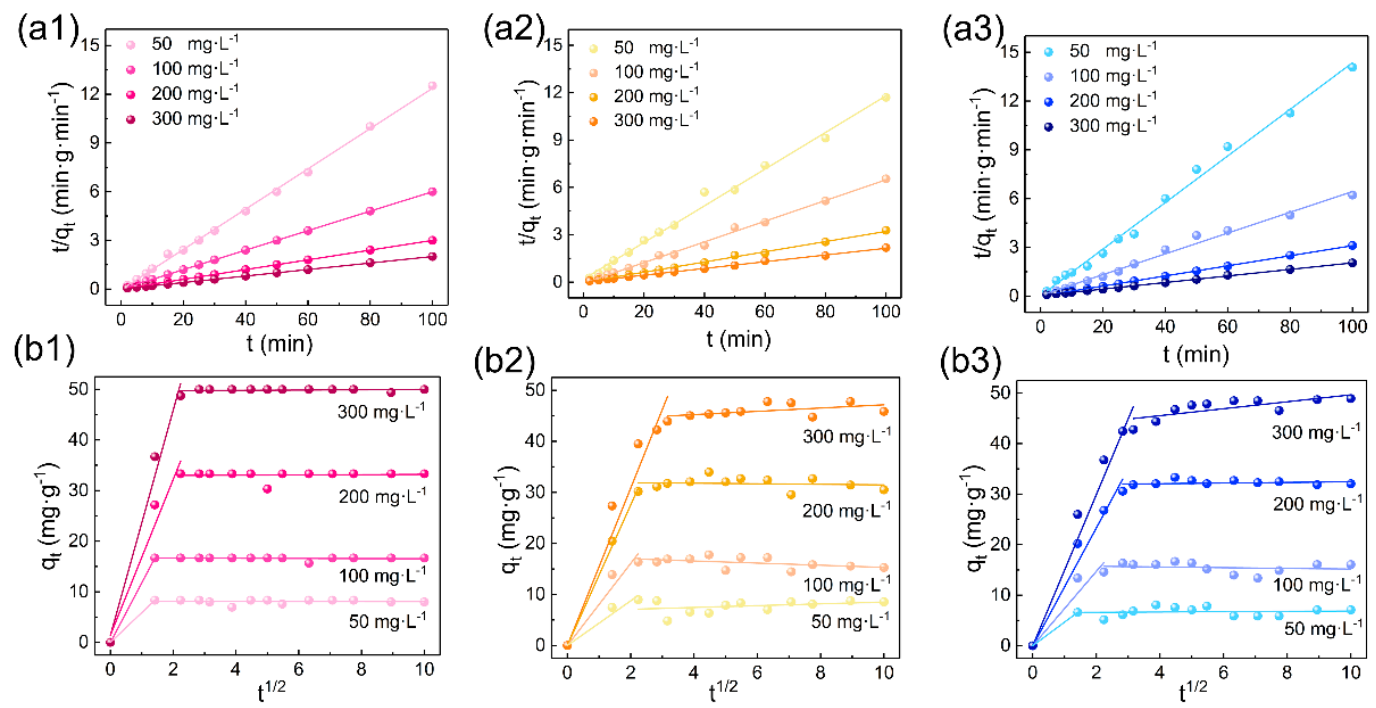

Figure 8. Pseudo-second order kinetics for the adsorption of (a1) RR120, (a2) RY167, and (a3) RB222 onto the CL powders, respectively $\left(\mathrm{m}=0.3 \mathrm{~g}, \mathrm{~V}=50 \mathrm{~mL}, \mathrm{C}_{0}=50,100,200\right.$, and $300 \mathrm{mg} \cdot \mathrm{L}^{-1}, \mathrm{~T}=30{ }^{\circ} \mathrm{C}$, $\mathrm{pH}=3.0$ ); intraparticle diffusion kinetics for the adsorption of (b1) RR120, (b2) RY167, and (b3) RB222 onto the CL powders, respectively $\left(\mathrm{m}=0.3 \mathrm{~g}, \mathrm{~V}=50 \mathrm{~mL}, \mathrm{C}_{0}=50,100,200\right.$, and $300 \mathrm{mg} \cdot \mathrm{L}^{-1}, \mathrm{~T}=30{ }^{\circ} \mathrm{C}$, $\mathrm{pH}=3.0)$. 
Table 2. Kinetic parameters of the pseudo-first order and pseudo-second order kinetic models for the adsorption of RR120, RY167, and RB222 onto the CL powders.

\begin{tabular}{|c|c|c|c|c|c|c|c|c|}
\hline \multirow{2}{*}{$\begin{array}{c}C_{0} \\
\left(\mathrm{mg} \cdot \mathrm{L}^{-1}\right)\end{array}$} & \multirow{2}{*}{ Dyes } & \multirow{2}{*}{$\underset{\left(\mathrm{mg} \cdot \mathrm{g}^{-1}\right)}{Q_{e, \exp }}$} & \multicolumn{3}{|c|}{ Pseudo-First Order } & \multicolumn{3}{|c|}{ Pseudo-Second Order } \\
\hline & & & $\begin{array}{c}k_{1} \\
\left(\min ^{-1}\right)\end{array}$ & $\begin{array}{c}Q_{e, c a l} \\
\left(\mathrm{mg}^{-\mathrm{g}^{-1}}\right)\end{array}$ & $R^{2}$ & $\begin{array}{c}k_{2} \\
\left(\mathrm{~g} \cdot \mathrm{mg}^{-1} \cdot \mathrm{min}^{-1}\right)\end{array}$ & $\begin{array}{c}Q_{e, c a l} \\
\left(\mathbf{m g} \cdot \mathbf{g}^{-1}\right)\end{array}$ & $R^{2}$ \\
\hline \multirow[t]{3}{*}{50} & RR120 & 7.9861 & 0.0187 & 1.0179 & 0.3029 & 0.4502 & 8.0626 & 0.9984 \\
\hline & RY167 & 8.5526 & 0.0336 & 1.1972 & 0.5204 & 0.0706 & 8.6118 & 0.9920 \\
\hline & RB222 & 7.1078 & 0.0034 & 1.6949 & 0.1497 & 0.1909 & 6.9818 & 0.9934 \\
\hline \multirow[t]{3}{*}{100} & RR120 & 16.667 & 0.0467 & 1.7518 & 0.5170 & 0.4081 & 16.667 & 0.9999 \\
\hline & RY167 & 15.278 & 0.0151 & 1.5394 & 0.1910 & 0.0602 & 15.258 & 0.9956 \\
\hline & RB222 & 16.071 & 0.0068 & 1.4082 & 0.2124 & 0.0831 & 15.654 & 0.9893 \\
\hline \multirow[t]{3}{*}{200} & RR120 & 33.378 & 0.0411 & 1.1530 & 0.5745 & 0.3771 & 33.378 & 0.9999 \\
\hline & RY167 & 30.503 & 0.0104 & 2.8279 & 0.1709 & 0.0518 & 30.503 & 0.9973 \\
\hline & RB222 & 32.068 & 0.0193 & 3.5523 & 0.2061 & 0.0222 & 32.227 & 0.9996 \\
\hline \multirow[t]{3}{*}{300} & RR120 & 50.000 & 0.0213 & 1.3612 & 0.2770 & 0.2391 & 49.900 & 0.9999 \\
\hline & RY167 & 45.856 & 0.0180 & 10.457 & 0.3515 & 0.0306 & 45.856 & 0.9984 \\
\hline & RB222 & 48.918 & 0.0309 & 12.086 & 0.5965 & 0.0113 & 49.617 & 0.9992 \\
\hline
\end{tabular}

Based on these results, it can be concluded that the CL powders showed excellent capability to remove reactive dyes from water. Additionally, the adsorption mechanism of the reactive dyes onto the $C L$ powders is rather complex, as both the external surface adsorption and intraparticle diffusion occurred simultaneously $[56,62]$.

\subsection{Comparison of CL with Other Powders}

Table 3 summarizes the maximum adsorption capacity of dyes by other low-cost powders. It shows that the CL powders prepared in this study had a superior adsorption capacity when compared with various previously reported powders. Figure 9 shows the proposed mechanism for the adsorption of reactive dyes onto the CL powders. Due to the ionization of sulfonic acid groups in the dye molecules, the RR120, RY167, and RB222 dye molecules are generally negatively charged in the acid aqueous solution [5]. However, the CL powders are mainly composed of amino acids, and there are many functional groups such as amino groups and carboxyl groups in the CL powders. Under acidic conditions, the inhibition for the ionization of carboxyl group contributes to the enhancement of positive charge on the CL powders. Therefore, CL powders are positively charged in an acidic aqueous solution. As a result, the electrostatic attraction between the negatively charged dye molecules and the positively charged CL powders will form, leading to the adsorption of reactive dyes onto the CL powder. Simultaneously, the adsorbed reactive dye molecules can be reacted with functional groups such as amino groups on the macro chains of CL powders via a nucleophilic substitution reaction for dye fixation, thus leading to the further adsorption of reactive dyes from bulk solution onto the CL powders. Based on the above results, the CL powders can be a promising adsorbent for the effective removal of dyes from wastewater.

Table 3. Maximum adsorption capacity $\left(Q_{\mathrm{m}}\right)$ of dyes onto the powders.

\begin{tabular}{cccc}
\hline Adsorbent & Dyes & $Q_{\mathbf{m}} \mathbf{( m g \cdot \mathbf { g } ^ { - \mathbf { 1 } } \text { ) }}$ & Ref. \\
\hline & Reactive red 120 & 167.0 & \\
Leather powder & Reactive yellow 167 & 178.9 & This work \\
& Reactive blue 222 & 129.5 & \\
Banana peel powder & Reactive black 5 & 49.20 & [8] \\
& Congo red & 164.6 & \\
Silk fibroin powder & Methylene blue & 20.58 & {$[16]$} \\
Down powder & Acid brilliant scarlet 3R & 147.7 & {$[32]$} \\
Mango seed kernel powder & Methylene blue & 142.9 & {$[63]$} \\
Neem tree leaf powder & Methylene blue & 30.66 & [64] \\
\hline
\end{tabular}




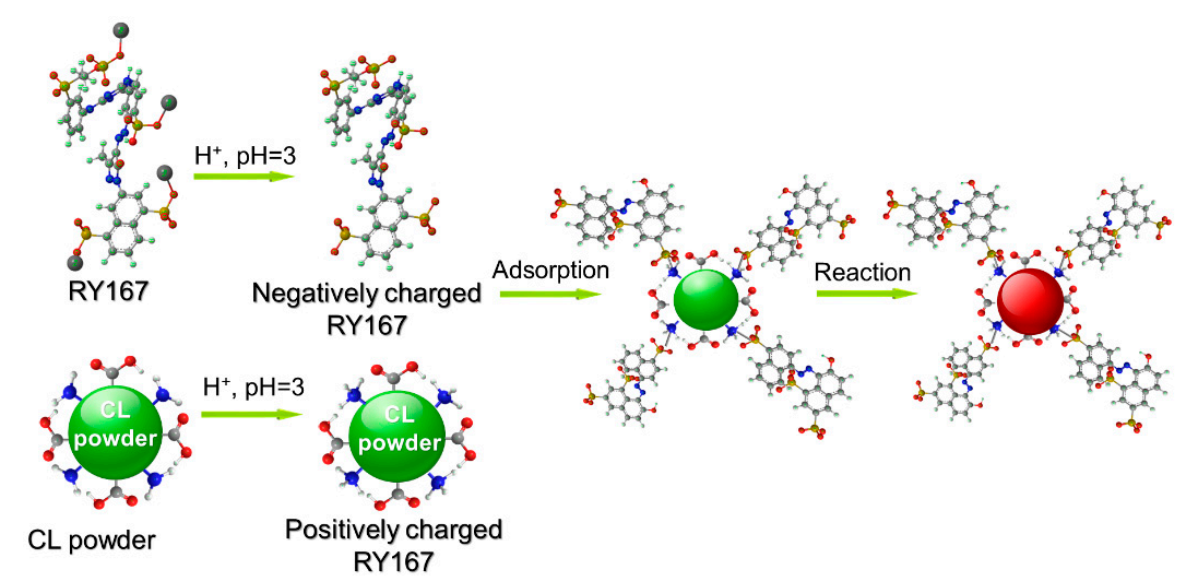

Figure 9. Proposed mechanism for the adsorption of reactive dyes onto the CL powders.

\section{Conclusions}

In summary, fine CL powders were successfully prepared using a homemade instrument at room temperature and atmospheric pressure. Dot-like particles with an average MFD of $1.6 \mu \mathrm{m}$, rod-like particles with an average MFD of $17.8 \mu \mathrm{m}$, and fiber-like particles with an average MFD of $40.1 \mu \mathrm{m}$ were achieved without a separation process. The CL powders exhibited a similar chemical structure and slightly lower crystallinity when compared with CL, which was confirmed using FTIR and XRD, respectively. An improvement in thermal stability was also observed for the CL powders. This method provides an alternative avenue for the reuse of primary and secondary leather waste. Moreover, dye removal experiments indicate that the prepared CL powders could be used for the effective removal of RR120, RY127, and RB222 with the adsorption capacity of 167.0, 178.9, and $129.6 \mathrm{mg} \cdot \mathrm{g}^{-1}$, respectively. The adsorption of reactive dyes onto the CL powders obeyed the Langmuir isotherm, and the pseudo-second-order and intraparticle diffusion models could well depict the adsorption kinetics. Therefore, the as-prepared CL powders can be used as a potential adsorbent in the treatment of dye contaminated wastewater. Future work will mainly focus on the application of the adsorbed CL powders for the pigment printing of textile materials.

Author Contributions: W.X. conceived the main idea and supervised the project. C.Z. designed the experiments. L.X. performed the experiments and wrote the manuscript with support from C.L., S.Z., and Z.F. X.L. provided significant guidance on the adsorption mechanism. J.Z., Y.W., and P.L. provided critical feedback and helped shape the research, analysis, and manuscript.

Funding: This research was funded by the National Natural Science Foundation of China (grant number 21905214) and the Excellent Young Science and Technology Innovation Team of Hubei High School (grant number T201707).

Conflicts of Interest: The authors declare no conflicts of interest.

\section{References}

1. Johnson, N.; Revenga, C.; Echeverria, J. Managing water for people and nature. Science 2001, 292, 1071-1072. [CrossRef] [PubMed]

2. Samanta, P.; Desai, A.V.; Let, S.; Ghosh, S.K. Advanced Porous Materials for Sensing, Capture and Detoxification of Organic Pollutants toward Water Remediation. ACS Sustain. Chem. Eng. 2019, 7, 7456-7478. [CrossRef]

3. Hasanbeigi, A.; Price, L. A technical review of emerging technologies for energy and water efficiency and pollution reduction in the textile industry. J. Clean. Prod. 2015, 95, 30-44. [CrossRef]

4. Hasan, M.; Gopakumar, D.A.; Arumughan, V.; Pottathara, Y.B.; Sisanth, K.S.; Pasquini, D.; Bracic, M.; Seantier, B.; Nzihou, A.; Thomas, S.; et al. Robust Superhydrophobic Cellulose Nanofiber Aerogel for Multifunctional Environmental Applications. Polymers 2019, 11, 495. [CrossRef]

5. Xia, L.; Wang, A.; Zhang, C.; Liu, Y.; Guo, H.; Ding, C.; Wang, Y.; Xu, W. Environmentally friendly dyeing of cotton in an ethanol-water mixture with excellent exhaustion. Green Chem. 2018, 20, 4473-4483. [CrossRef] 
6. Yokwana, K.; Kuvarega, A.T.; Mhlanga, S.D.; Nxumalo, E.N. Mechanistic aspects for the removal of Congo red dye from aqueous media through adsorption over N-doped graphene oxide nanoadsorbents prepared from graphite flakes and powders. Phys. Chem. Earth 2018, 107, 58-70. [CrossRef]

7. Hao, Y.; Wang, Z.; Wang, Z.; He, Y. Preparation of hierarchically porous carbon from cellulose as highly efficient adsorbent for the removal of organic dyes from aqueous solutions. Ecotoxicol. Environ. Saf. 2019, 168, 298-303. [CrossRef]

8. Munagapati, V.S.; Yarramuthi, V.; Kim, Y.; Lee, K.M.; Kim, D.S. Removal of anionic dyes (Reactive Black 5 and Congo Red) from aqueous solutions using Banana Peel Powder as an adsorbent. Ecotoxicol. Environ. Saf. 2018, 148, 601-607. [CrossRef]

9. Guo, W.; Xia, T.; Pei, M.; Du, Y.; Wang, L. Bentonite Modified by Allylamine Polymer for Adsorption of Amido Black 10B. Polymers 2019, 11, 502. [CrossRef]

10. Xue, J.; Song, F.; Yin, X.-W.; Zhang, Z.-L.; Liu, Y.; Wang, X.-L.; Wang, Y.-Z. Cellulose Nanocrystal-Templated Synthesis of Mesoporous $\mathrm{TiO}_{2}$ with Dominantly Exposed (001) Facets for Efficient Catalysis. ACS Sustain. Chem. Eng. 2017, 5, 3721-3725. [CrossRef]

11. Zhang, J.; Li, Y.; Li, L.; Li, W.; Yang, C. Dual Functional N-Doped $\mathrm{TiO}_{2}$-Carbon Composite Fibers for Efficient Removal of Water Pollutants. ACS Sustain. Chem. Eng. 2018, 6, 12893-12905. [CrossRef]

12. Allègre, C.; Moulin, P.; Maisseu, M.; Charbit, F. Treatment and reuse of reactive dyeing effluents. J. Membr. Sci. 2006, 269, 15-34. [CrossRef]

13. Capar, G.; Yetis, U.; Yilmaz, L. Membrane based strategies for the pre-treatment of acid dye bath wastewaters. J. Hazard Mater. 2006, 135, 423-430. [CrossRef] [PubMed]

14. Varaprasad, K.; Jayaramudu, T.; Sadiku, E.R. Removal of dye by carboxymethyl cellulose, acrylamide and graphene oxide via a free radical polymerization process. Carbohydr. Polym. 2017, 164, 186-194. [CrossRef]

15. Daneshvar, N.; Khataee, A.R.; Rasoulifard, M.H.; Pourhassan, M. Biodegradation of dye solution containing Malachite Green: Optimization of effective parameters using Taguchi method. J. Hazard Mater. 2007, 143, 214-219. [CrossRef]

16. Xiao, S.; Wang, Z.; Ma, H.; Yang, H.; Xu, W. Effective removal of dyes from aqueous solution using ultrafine silk fibroin powder. Adv. Powder Technol. 2014, 25, 574-581. [CrossRef]

17. Kolomaznik, K.; Adamek, M.; Andel, I.; Uhlirova, M. Leather waste-Potential threat to human health, and a new technology of its treatment. J. Hazard Mater. 2008, 160, 514-520. [CrossRef]

18. Przepiorkowska, A.; Chronska, K.; Zaborski, M. Chrome-tanned leather shavings as a filler of butadiene-acrylonitrile rubber. J. Hazard Mater. 2007, 141, 252-257. [CrossRef]

19. Ogino, H.; Otsubo, T.; Ishikawa, H. Screening, purification, and characterization of a leather-degrading protease. Biochem. Eng. J. 2008, 38, 234-240. [CrossRef]

20. Ravichandran, K.; Natchimuthu, N. Vulcanization characteristics and mechanical properties of natural rubber-scrap rubber compositions filled with leather particles. Polym. Int. 2005, 54, 553-559. [CrossRef]

21. El-Sabbagh, S.H.; Mohamed, O.A. Recycling of chrome-tanned leather waste in acrylonitrile butadiene rubber. J. Appl. Polym. Sci. 2011, 121, 979-988. [CrossRef]

22. Santos, R.J.; Agostini, D.L.S.; Cabrera, F.C.; Budemberg, E.R.; Job, A.E. Recycling leather waste: Preparing and studying on the microstructure, mechanical, and rheological properties of leather waste/rubber composite. Polym. Compos. 2014, 36, 2275-2281. [CrossRef]

23. Ambrósio, J.D.; Lucas, A.A.; Otaguro, H.; Costa, L.C. Preparation and characterization of poly (vinyl butyral)-leather fiber composites. Polym. Compos. 2011, 32, 776-785. [CrossRef]

24. Mohamed, O.A.; El Sayed, N.H.; Abdelhakim, A.A. Preparation and characterization of polyamide-leather wastes polymer composites. J. Appl. Polym. Sci. 2010, 118, 446-451. [CrossRef]

25. Swarnalatha, S.; Ganesh Kumar, A.; Tandaiah, S.; Sekaran, G. Efficient and safe disposal of chrome shavings discharged from leather industry using thermal combustion. J. Chem. Technol. Biot. 2009, 84, 751-760. [CrossRef]

26. Yılmaz, O.; Cem Kantarli, I.; Yuksel, M.; Saglam, M.; Yanik, J. Conversion of leather wastes to useful products. Resour. Conserv. Recycl. 2007, 49, 436-448. [CrossRef]

27. Deng, D.; Liao, X.; Shi, B. Synthesis of porous carbon fibers from collagen fiber. ChemSusChem 2008, 1, 298-301. [CrossRef] [PubMed] 
28. Nogueira, F.G.; Castro, I.A.; Bastos, A.R.; Souza, G.A.; de Carvalho, J.G.; Oliveira, L.C. Recycling of solid waste rich in organic nitrogen from leather industry: Mineral nutrition of rice plants. J. Hazard Mater. 2011, 186, 1064-1069. [CrossRef] [PubMed]

29. Lazău, R.I.; Păcurariu, C.; Becherescu, D.; Ianoş, R. Ceramic pigments with chromium content from leather wastes. J. Eur. Ceram. Soc. 2007, 27, 1899-1903. [CrossRef]

30. Kamranifar, M.; Khodadadi, M.; Samiei, V.; Dehdashti, B.; Noori Sepehr, M.; Rafati, L.; Nasseh, N. Comparison the removal of reactive red 195 dye using powder and ash of barberry stem as a low cost adsorbent from aqueous solutions: Isotherm and kinetic study. J. Mol. Liq. 2018, 255, 572-577. [CrossRef]

31. Chen, F.; Xiong, L.; Cai, M.; Xu, W.; Liu, X. Adsorption of direct fast scarlet 4BS dye from aqueous solution onto natural superfine down particle. Fiber Polym. 2015, 16, 73-78. [CrossRef]

32. Chen, F.; Liu, X.; Dong, B.; Zhou, Y.; Hu, H.; Xiao, X.; Liu, K.; Zhang, C.; Yuan, T.; Liang, Z.; et al. Preparation of superfine down particles derived from down fiber wastes and their application as an efficient adsorbent toward acid brilliant scarlet 3R. Text. Res. J. 2015, 86, 1050-1062. [CrossRef]

33. Chen, F.; Liu, X.; Liu, K.; Xiao, X.; Zhang, C.; Cheng, F.; Xia, L.; Zhou, Y.; Dong, B.; Wan, L.; et al. The adsorption performance of Vat Scarlet R on natural superfine needle down particles. Color. Technol. 2016, 132, $28-34$. [CrossRef]

34. Xu, W.; Cui, W.; Li, W.; Guo, W. Development and characterizations of super-fine wool powder. Powder Technol. 2004, 140, 136-140. [CrossRef]

35. Zhu, L.; Xu, W.; Ma, M.; Zhou, H. Effect of plasma treatment of silk fibroin powder on the properties of silk fibroin powder/polyurethane blend film. Poly. Eng. Sci. 2010, 50, 1705-1712. [CrossRef]

36. Xu, W.; Wang, X.; Cui, W.; Peng, X.; Li, W.; Liu, X. Characterization of superfine down powder. J. Appl. Polym. Sci. 2009, 111, 2204-2209. [CrossRef]

37. Khatri, A.; Peerzada, M.H.; Mohsin, M.; White, M. A review on developments in dyeing cotton fabrics with reactive dyes for reducing effluent pollution. J. Clean. Prod. 2015, 87, 50-57. [CrossRef]

38. Papic, S. Removal of some reactive dyes from synthetic wastewater by combined Al (III) coagulation/carbon adsorption process. Dyes Pigments 2004, 62, 291-298. [CrossRef]

39. Deng, S.; Zhang, G.; Chen, S.; Xue, Y.; Du, Z.; Wang, P. Rapid and effective preparation of a HPEI modified biosorbent based on cellulose fiber with a microwave irradiation method for enhanced arsenic removal in water. J. Mater. Chem. A 2016, 4, 15851-15860. [CrossRef]

40. Wang, Z.; Zhang, J.-H.; Jiang, J.-J.; Wang, H.-P.; Wei, Z.-W.; Zhu, X.; Pan, M.; Su, C.-Y. A stable metal cluster-metalloporphyrin MOF with high capacity for cationic dye removal. J. Mater. Chem. A 2018, 6, 17698-17705. [CrossRef]

41. Mamane, H.; Kohn, C.; Adin, A. Characterizing Shape of Effluent Particles by Image Analysis. Sep. Sci. Technol. 2008, 43, 1737-1753. [CrossRef]

42. Walton, W.H. Feret's Statistical Diameter as a Measure of Particle Size. Nature 1948, 162, 329-330. [CrossRef]

43. Mazzoli, A.; Favoni, O. Particle size, size distribution and morphological evaluation of airborne dust particles of diverse woods by Scanning Electron Microscopy and image processing program. Powder Technol. 2012, 225, 65-71. [CrossRef]

44. Chen, J.; Gao, J.; Wu, J.; Zhang, M.; Cai, M.; Xu, H.; Jiang, J.; Tian, Z.; Wang, H. Revealing the carbohydrate pattern on a cell surface by super-resolution imaging. Nanoscale 2015, 7, 3373-3380. [CrossRef] [PubMed]

45. Kaye, B.H. Some aspects of the efficiency of statistical methods of particle size analysis. Powder Technol. 1968, 2, 97-110. [CrossRef]

46. Chen, X.; Li, W.; Zhong, W.; Lu, Y.; Yu, T. pH sensitivity and ion sensitivity of hydrogels based on complex-forming chitosan/silk fibroin interpenetrating polymer network. J. Appl. Polym. Sci. 1997, 65, 2257-2262. [CrossRef]

47. Kozlovskaya, V.; Baggett, J.; Godin, B.; Liu, X.; Kharlampieva, E. Hydrogen-Bonded Multilayers of Silk Fibroin: From Coatings to Cell-Mimicking Shaped Microcontainers. ACS Macro Lett. 2012, 1, 384-387. [CrossRef]

48. Li, C.; Xue, F.; Ding, E. Fabrication and characterisation of ultrafine leather powder: A functional reinforcement containing $\mathrm{SiO}_{2}$ particles. Micro Nano Lett. 2014, 9, 308-311. [CrossRef]

49. Xia, L.; Zhang, C.; Xu, W.; Zhu, K.; Wang, A.; Tian, Y.; Wang, Y.; Xu, W. Protective Bleaching of Camel Hair in a Neutral Ethanol(-)Water System. Polymers 2018, 10, 730. [CrossRef] 
50. Xu, W.; Guo, W.; Li, W. Thermal analysis of ultrafine wool powder. J. Appl. Polym. Sci. 2003, 87, $2372-2376$. [CrossRef]

51. Liu, X.; Gu, S.; Xu, W. Thermal and structural characterization of superfine down powder. J. Therm. Anal. Calorim. 2012, 111, 259-266. [CrossRef]

52. Değermenci, G.D.; Değermenci, N.; Ayvaoğlu, V.; Durmaz, E.; Çakır, D.; Akan, E. Adsorption of reactive dyes on lignocellulosic waste; characterization, equilibrium, kinetic and thermodynamic studies. J. Clean. Prod. 2019, 225, 1220-1229. [CrossRef]

53. Perez-Ameneiro, M.; Vecino, X.; Cruz, J.M.; Moldes, A.B. Physicochemical study of a bio-based adsorbent made from grape marc. Ecol. Eng. 2015, 84, 190-193. [CrossRef]

54. Das, S.; Chakraborty, P.; Ghosh, R.; Paul, S.; Mondal, S.; Panja, A.; Nandi, A.K. Folic Acid-Polyaniline Hybrid Hydrogel for Adsorption/Reduction of Chromium (VI) and Selective Adsorption of Anionic Dye from Water. ACS Sustain. Chem. Eng. 2017, 5, 9325-9337. [CrossRef]

55. Chen, H.; Wageh, S.; Al-Ghamdi, A.A.; Wang, H.; Yu, J.; Jiang, C. Hierarchical C/NiO-ZnO nanocomposite fibers with enhanced adsorption capacity for Congo red. J. Coll. Interface Sci. 2019, 537, 736-745. [CrossRef]

56. Qi, G.; Hai, C.; Shen, Y.; Zeng, J.; Li, X.; Ren, X.; Sun, Y.; Dong, S.; Zhou, Y. Synthesis of mono-dispersed mesoporous $\mathrm{Mn}_{2} \mathrm{O}_{3}$ powders with micro-nanostructure for removing Congo red dye from aqueous solution. Adv. Powder Technol. 2019, 30, 930-939. [CrossRef]

57. Kim, H.R.; Jang, J.W.; Park, J.W. Carboxymethyl chitosan-modified magnetic-cored dendrimer as an amphoteric adsorbent. J. Hazard Mater. 2016, 317, 608-616. [CrossRef]

58. Chen, J.; Sheng, Y.; Song, Y.; Chang, M.; Zhang, X.; Cui, L.; Meng, D.; Zhu, H.; Shi, Z.; Zou, H. Multimorphology Mesoporous Silica Nanoparticles for Dye Adsorption and Multicolor Luminescence Applications. ACS Sustain. Chem. Eng. 2018, 6, 3533-3545. [CrossRef]

59. Perez-Ameneiro, M.; Bustos, G.; Vecino, X.; Barbosa-Pereira, L.; Cruz, J.M.; Moldes, A.B. Heterogenous Lignocellulosic Composites as Bio-Based Adsorbents for Wastewater Dye Removal: A Kinetic Comparison. Water Air Soil Pollut. 2015, 226. [CrossRef]

60. Perez-Ameneiro, M.; Vecino, X.; Barbosa-Pereira, L.; Cruz, J.M.; Moldes, A.B. Removal of pigments from aqueous solution by a calcium alginate-grape marc biopolymer: A kinetic study. Carbohydr. Polym. 2014, 101, 954-960. [CrossRef]

61. Perez-Ameneiro, M.; Vecino, X.; Cruz, J.M.; Moldes, A.B. Wastewater treatment enhancement by applying a lipopeptide biosurfactant to a lignocellulosic biocomposite. Carbohydr. Polym. 2015, 131, 186-196. [CrossRef] [PubMed]

62. Razmi, F.A.; Ngadi, N.; Wong, S.; Inuwa, I.M.; Opotu, L.A. Kinetics, thermodynamics, isotherm and regeneration analysis of chitosan modified pandan adsorbent. J. Clean. Prod. 2019, 231, 98-109. [CrossRef]

63. Kumar, K.V.; Kumaran, A. Removal of methylene blue by mango seed kernel powder. Biochem. Eng. J. 2005, 27, 83-93. [CrossRef]

64. Bhattacharyya, K.; Sharma, A. Kinetics and thermodynamics of Methylene Blue adsorption on Neem (Azadirachta indica) leaf powder. Dyes Pigments 2005, 65, 51-59. [CrossRef]

(C) 2019 by the authors. Licensee MDPI, Basel, Switzerland. This article is an open access article distributed under the terms and conditions of the Creative Commons Attribution (CC BY) license (http://creativecommons.org/licenses/by/4.0/). 